\begin{tabular}{|l|l|l||}
\hline \multicolumn{2}{|c|}{ PublisherInfo } \\
\hline \hline PublisherName & $:$ & BioMed Central \\
\hline \hline PublisherLocation & $:$ & London \\
\hline \hline PublisherImprintName & $:$ & BioMed Central \\
\hline \hline
\end{tabular}

\title{
Mitochondrial redox state in the critically ill
}

\begin{tabular}{|l|l|l||}
\hline \multicolumn{2}{|c|}{ ArticleInfo } \\
\hline \hline ArticleID & $:$ & 4086 \\
\hline \hline ArticleDOI & $:$ & $10.1186 /$ ccf-1999-1341 \\
\hline \hline ArticleCitationID & $:$ & 1341 \\
\hline \hline ArticleSequenceNumber & $:$ & 23 \\
\hline \hline ArticleCategory & $:$ & Paper Report \\
\hline ArticleFirstPage & $:$ & 1 \\
\hline \hline ArticleLastPage & $:$ & 3 \\
\hline \hline & & RegistrationDate : 1999-8-16 \\
\hline ArticleHistory & $:$ & OnlineDate \\
\hline \hline ArticleCopyright & $:$ & Current Science Ltd1999-8-16 \\
\hline \hline ArticleGrants & $:$ & \\
\hline \hline ArticleContext & $:$ & 130541111 \\
\hline \hline
\end{tabular}




\section{Keywords}

Blood, complications, intensive care, ketone bodies, lactate, metabolism, metabolism, oxygen consumption, septic shock

\section{Comments}

Although this study only uses a small sample, the results are very interesting and certainly should stimulate further study in ITU populations. It may be useful in identifying potential non-survivors, and directing therapy to return the redox state to normal in these patients.

\section{Introduction}

Multi-organ failure is well known to be associated with high mortality and morbidity in the ITU population. In some patients, metabolic changes occur with an adaptive fat metabolism, preferring fat rather than carbohydrate as an energy source. It has been suggested that such pathophysiological changes 'poison' mitochondria, suppressing energy production and resulting in a decrease in the amount of reserve energy. A key role in the function of mitochondria is the NAD/NADH couple that is the first stage of the mitochondrial respiratory chain. It has been previously shown that after administration of a large dose of glucose to suppress gluconeogensis, the arterial blood ketone body ratio (AKBR) (which is the ratio of acetoacetate to beta-hydroxybutyrate) closely correlates with the mitochondrial redox state. Although the AKBR has been measured in patients undergoing liver transplantation, it had not been previously measured in critically ill patients.

\section{Aims}

This study aimed to evaluate the time course and extent of redox changes in the critically ill population using the AKBR.

\section{Methods}


Twenty patients presenting to a single ITU were enrolled in the study, ten of whom had septic shock and ten who had non-sepsis related conditions requiring ITU admission. For the patient to enter the study, their APACHE II scores had to exceed 15. Standard therapy was administered as usual. Blood was taken from an indwelling arterial line $30 \mathrm{~min}$ after the intravenous administration of a bolus of $15 \mathrm{~g}$ of glucose. Sampling points were the day of ITU admission (day 1), $24 \mathrm{~h}$ later (day 2) and $48 \mathrm{~h}$ after admission (day 3). Plasma from the samples was analysed for AKBR (quantitative measurement of acetoacetate and beta-hydroxybutyrate) and for lactate.

\section{Results}

In the patients who died, the AKBR decreased significantly over the three days studied. In the patients who survived, the AKBR increased. There was a significant difference between survivors and nonsurvivors $(p=0.015)$. The AKBR was less than 0.4 in all non-surviving patients by day 3 . Plasma lactate levels were significantly higher on days two and three in non-survivors compared to survivors.

\section{Discussion}

This study demonstrates that AKBR was lower in the patients who died than in the survivors. Subgroup analysis showed that, in the group of patients who died, those who had septic shock showed a significant decrease in AKBR over the three days. The changes in AKBR reflect changes in hepatic mitochondrial redox state. As the AKBR decreases, the alteration in redox state results in decreased levels of NADH available for the conversion of acetoacetate to beta-hydroxybutyrate.

The authors suggest that AKBR may be a useful marker of hepatic oxygenation. They also suggest that AKBR should now be compared with other markers of tissue oxygenation, and the outcome effects of modifying AKBR should also be studied.

\section{References}

1. Yassen KA, Galley HF, Lee A, Webster NR: Mitochondrial redox state in the critically ill. Br J Anaesth. 1999, 83: 325-327.

This PDF file was created after publication. 